\title{
Investigating the impact of environmental attitude on the decision to purchase a green product with the mediating role of environmental concern and care for green products
}

\author{
Majid ESMAEILPOUR \\ Persian Gulf University, Bushehr, Iran \\ majidesmailpour@pgu.ac.ir \\ Elahe BAHMIARY \\ Persian Gulf University, Bushehr, Iran
}

\begin{abstract}
The intention to purchase green products is the tendency of a person who prefers to purchase a product with optimal environmental characteristics rather than usual products. Nowadays, the environment is very important and maintaining it is a vital issue for all groups of people, whether in the customer's position or in the distributor's position. However, in spite of the increased environmental awareness among consumers and encouragements made by producers for them to buy green products, we require further investigation in this area in order to increase green purchasing among different group of people. The main objective of this study is to investigate the impact of the environmental attitude on the decision to purchase a green product with the mediating role of environmental concerns and care for green products. This research is an applied research, and correlational-descriptive in terms of data analysis. The research population includes consumers from Bushehr city, sampled based on availability. In this research, 300 questionnaires were distributed among consumers. Structural equation modeling was used to analyze the data. The findings of this research showed that the environmental attitude of customers has significant and positive impact on caring for green products and environmental concerns. In addition, environmental concerns and care for green products have a significant and positive impact on green purchasing decision.
\end{abstract}

Keywords: environmental attitude, environmental concerns, care for green products, consumer, decision to purchase a green product.

Please cite the article as follows: Esmaeilpour, M. and Bahmiary, E. (2017), "Investigating the impact of environmental attitude on the decision to purchase a green product with the mediating role of environmental concern and care for green products", Management \& Marketing. Challenges for the Knowledge Society, Vol. 12, No. 2, pp. 297-315. DOI: 10.1515/mmcks-2017-0018.

\section{Introduction}

Since the beginning, human beings have found that their survival depends on harmony with nature and that the destruction of nature is their destruction too. However, with the growth of human capabilities in recent centuries, the environmental equilibrium was disrupted. Being aware of the destruction of natural resources as a result of human activities and the need for the preservation of the environment have increased environmental awareness of consumers' behavior (Kumar and Ghodeswar, 2015). Growing environmental problems caused by industrialization have increased the environmental concerns of customers, communities, and governments (Chiou et al., 2011). In this regard, green marketing 
and encouraging consumers to behave environment-friendly are important from two perspectives. On the one hand, the increasing use and destruction of natural resources such as water, oil and forests, which are essential for the survival of human beings, is considered a serious risk for human, and is indicative of the necessity of encouraging people for environment-friendly behavior or so-called green behavior. On the other hand, consumers' concern in relation to environmental problems is increasing. This means that an increasing number of people tend to purchase and consume products that are presented in an environment-friendly way (Hosseini and Ziaee Bideh, 2014). Nowadays, most consumers have become aware that their purchasing behavior directly affects environmental issues. This has led them to act conscientiously and buy goods which cause no harm to the environment (Elahi and Yaghoubi, 2012). In other words, environmental issues and preserving the environment are among the criteria that people consider when purchasing goods and services (Juwaheer et al., 2012). As it has been shown in many studies, consumers are willing to pay more for green products (Newton et al., 1981). In addition, the innovative role of producers in displaying their green products has increased (Kumar, 2001).

The number of studies on green consumer behavior during the past decade has increased and contributed to the studies conducted on environmental attitudes and their effect on consumers' behavior. This change in consumer behavior has helped the beginning of green revolution meant to avoid further harm to the environment (Juwaheer et al., 2012). Thus, the issue of preserving our environment has caused consumers to rethink their choice of products and for the protection of the environment, many consumers are ready to pay higher prices for products that comply with environmental standards (Newton et al., 2015). The impact of this is seen when companies and organizations are turning more towards environmentfriendly products (Finisterra et al., 2009).

In Iran, the market for environment-friendly products is growing and the government is putting pressure on firms and consumers for the production and consumption of these products. Paying attention to factors that affect customer selection process and type of consumers' reaction to these products is very important. Today, it seems that there is an increasing demand for products that not only meet the immediate needs of consumers, but benefit the environment in longterm as well. In this respect, marketing managers need to know that the criteria through which consumers used to evaluate the products have changed (Khorshidi et al., 2010). It does not seem possible to take advantage of a competitive market unless one knows about the tendency of consumers to purchase products compatible with the environment, and the category of products which make designing marketing strategies effective and practical. For this reason, this research is an attempt to evaluate the level of awareness of consumers about green marketing, their environmental attitudes toward it and its impact on their green purchasing decisions. The results of this research are useful for producers of various consumer products which can use them in their marketing plans. Companies' lack of knowledge about the level of awareness consumers have regarding products will cause the failure of implementation stage or undesired consequences. 


\section{Research literature review}

The occurrence of unusual atmospheric phenomena, such as the destruction of the ozone layer, has increased the amount of greenhouse gases. This is one of the most important factors in global warming and increasing environmental pollution which have affected all people in the world. In recent years, a growing concern about the environment has emerged among experts in all areas of science. It should be remembered that environmental issues have become critical and vital issues for all people, whether in customer position or in producer position. In addition, as traditional marketing overemphasizes customer needs, and does not consider social well-being and environmental problems, this issue has penetrated in all aspects of organizations including marketing, and has led to the emergence of the green marketing concept (Ranaee and Yari, 2013). Perhaps no one imagined that one day marketing would be concerned about consumers' health in addition to profitability and sales. However, an increasing concern towards the environment as well as the state regulations and increasing awareness of consumers have made companies reflect on the physical and mental health of consumers' environment. With the increase in the level of pollution every year and consumers' willingness to consider this issue in their consumptions, environmental products have become an important issue for producers and consumers (Crié and Magnier, 2015).

\section{Environmental attitude of consumers}

Attitudes are emotional senses that people have about a phenomenon which have an important role in predicting consumers' behavior (Abedi and Hasani, 2015). Environmental attitude is defined as a set of beliefs, desires as well as emotions and behavioral intentions related to environment (Abbasi et al., 2013) which might turn into an intention to do something (Ramayah et al., 2010). Environment-friendly attitude is defined as an attitude in which environmental consequences are considered. This attitude is directly influenced by personal experiences and those obtained as a result of contact with other people and the media (Paço and Raposo, 2009). The environmental attitude is assessed in terms of the consequences perceived by customers. The environmental consequences can be measured and assessed based on concerns about the impact of a product on the environment, destruction of forests, and the rate of use of energy in production of a product (Ramayah et al., 2010). The level of environmental concern of a person is associated with his attitude and behavior (Newton et al., 2015).

\section{Consumer's environmental concern}

Environmental concerns mean one's consciousness toward environmental problems and the desire to solve these problems (Singh and Bansal, 2012). International research has shown that consumers are more concerned about environmental changes and, in this regard, have changed their behavior (Papadopoulos et al., 2010). Community's concern about the environment has led to the emergence of a new type of consumers indicating their concerns in purchasing decisions (Chamorro and Banegil, 2006). Consumers concerned about the environment purchase goods 
and services that they think have positive impact (or less negative impact) on the environment. Such people are looking to limit the conscious use of products made of scarce resources, and to make an effort to save energy and refuse purchasing the products that have inappropriate and additional packaging (Albayrak et al., 2013). Nowadays, concern for the environment is observable in the purchasing models of consumers who prefer environment-friendly products (Paço and Raposo, 2009). Related research carried out shows that the majority of consumers (87 percent) are concerned about the environment and social impacts of the products that they purchase (Bonini and Oppenheim, 2008). Matthes et al. (2000) believe that three concepts of environmental concern include attitude towards green products, green purchasing behavior, and concepts relating to environmental involvement.

\section{Marketing and green marketing}

Experts have proposed various definitions for marketing, but the definition provided by Kotler has been welcomed highly among executive and scientific communities. According to Kotler, marketing is a business, a humanistic and social activity for satisfying the needs and desires of the community through the process of exchange (Rusta et al., 2008). The concept of green marketing emerged in the 1980s (Peattie and Crane, 2005), and was associated with changes in attitudes and behaviour of consumers which are formed for the first time (Chahal et al., 2014) when they pay more attention to activities protecting the environment. To satisfy the needs of consumers, green marketing developed in a new context of marketing and included all activities designed to minimize the damage to the environment as a result of producing a goods. This is how it tries to satisfy the needs and desires of individuals. Green marketing means trying to design, promote, price, and distribute products which are not harmful for the environment (Chan, 2013). Green marketing is a process that involves all marketing activities which seek to stimulate and maintain environmental attitudes and behaviour of consumers (Chen \& Chang, 2013). Green marketing encourages consumers to consider environmental and social standards at the time of purchasing, using and disposing of wastes (Belz and Peattie, 2009).

\section{Green consumer}

Nowadays, consumers are largely aware of environmental and social issues (Chen and Chang, 2013). People's concerns about their environment has led to the emergence of a new type of consumers indicating their concerns in their purchasing decisions. These consumers are known as green consumers (Nakhee and Kheiri, 2013). They are people who are very concerned about the natural environment and have modified their purchasing behaviors in order to protect the environment by purchasing products that are environmentally healthy (Lu et al., 2013). These consumers examine the impact of the production and consumption process of the products on the environment in their purchasing behavior and make decisions accordingly. Green consumers want products which protect the environment and which have benefits for them as well (Montague and Mukherjee, 2011). Generally, these consumers avoid buying products that may endanger their health and others', impose serious environmental damage during the production process, consume a 
lot of energy, create much waste, and impose harm on plants and animals going extinct in the extraction the primary and basic materials (Lee, 2008).

\section{Green products}

Green products are the kind of products that are designed in such a way as to have the least environmental impact during their production and consumption. A green product helps protect and improve the natural environment by conserving energy or resources, and by reducing or eliminating the use of toxic substances, pollution, and wastes (Kamble, 2007). In other words, a green product is the product that is less harmful to the environment (Lassner and Schubert, 2007). Green products with varying degrees improve positive effects on environment (or less negative), while other products would not reduce negative environmental impacts (Borin et al., 2011). According to another definition, a green product is a product that has such criteria and is designed in a way to be used, assembled, and reproduced. Also, in its production process, the kind of materials are used which could be recycled. In terms of energy, it has efficiency and produces less environmental pollution compared to the other products (Dangelico \& Pontrandolfo, 2009).

\section{Care for green products}

The fact that industrial organizations and consumers are paying attention to the environment is due to several reasons. Organizations have turned towards green strategies because of government pressure, exploitation of the opportunities inherent in green marketing, responding to social responsibility, tending to satisfy the needs of consumers who are aware of the organization's social responsibility and confrontation with the green practices of competitors. Although these are good reasons for changing the behavior and strategies of organizations, the important point is the use of this approach as a marketing tool (Polonsky, 1995). Management support of environmental issues and using management strategies can convert the threat of environmental issues into opportunities for competitive opportunities. Management support of green products results in innovative technologies that have positive impact on energy saving and the prevention of environmental pollution. Protecting practices of the environment in the long-term would become an organizational culture and in addition to reducing costs creates an advantage for organizations. The continuation of this process can be also considered as an important advantage for the organization from the perspective of customers concerned about environment (Salarzehi and Jahromy, 2015). Evidence suggests that many consumers are prepared to pay much more money for products that comply with environmental standards to support the environment. This indicates the importance of environmental issues for consumers and sellers. Consumers recognize the importance of green products and gather the related information when interact with others (Oliver and Lee, 2010). Many scholars argue that people who have high levels of concern about the environment will more probably show conscious behaviour toward the environment (Czap, 2010). 


\section{Decision to purchase a green product}

Green purchase decision means adding environmental aspects to criteria such as price and efficiency used when purchasing a product. Its final goal is the reduction of the environmental impact in sourcing and increasing resource productivity (Ranaee, Yari, 2013). Protection of environment is one of the main reasons of consumers to behave in an environment-friendly way in their purchasing decisions (Gadenne et al., 2011). The green product purchase decision is influenced by two main factors: the first group is a set of factors that are inherent to the consumer such as environmental responsibility, gaining knowledge, passion for and willingness to conserve resources, and reduce the environmental impacts. The second group is made out of external factors such as the features of the product such as product quality, efficiency, price, and promotion (Kumar and Ghodeswar, 2015). Several factors influence the environment-friendly purchasing behaviour. Researchers have divided them into two categories: internal and external factors. Internal factors include attitudes, values and beliefs (Cleveland et al., 2005), environmental concerns and environmental knowledge (Brécard et al., 2009), the realization of environmental responsibility, a desire to preserve the environment and reducing the environmental impacts (Kumar and Ghodeswar, 2015). External factors include access to environmental goods and services, economic factors (Stern, 2000), and features related to product, such as quality, efficiency, price, and health (Kumar and Ghodeswar, 2015).

\section{Experimental literature of research}

Kumar and Ghodeswar (2015) conducted a research about the factors influencing the decision to purchase a green product. The results showed that the respondents desire to preserve the environment, realize their environmental responsibility, have willingness to gain knowledge and learn about green products. Support for environment preservation, driving with environmental responsibility, experiencing a green product, friendship of firms with environment and social responsibility were stated as the most important factors influencing the decision to purchase green products. Newton et al. (2015) in their research investigated the direct and indirect effects of environmental concerns on the intention for environmental purchasing. They considered the impact of learning strategies as mediating variable. The results showed that environmental concerns affect intention to purchase directly, while they indirectly affect intention to purchase through mediating role of learning. Biswas and Mousumi (2015) conducted a research to explore the relationship between environmental concerns and the selected behavior of consumers in their intention to purchase green products in India as one of the developing East Asian societies. The results of their research showed that price sensitivity is the first priority in their selection, and social value is an important factor affecting the sustainable consumption behavior. In addition, the value of consumption varies among consumers with different preferences for green products. Abedi and Hasani (2015) investigated the effect of the marketing mix, oral communication, and satisfaction on consumers' attitudes towards products compatible with environment, and their purchase intention in non-durable products. The results indicate a significant relationship between marketing mix, oral 
communication and satisfaction, and consumer attitudes towards products compatible with the environment. In addition, consumers' attitude is significantly correlated with their purchase intention.

Bertrandias and Gambier (2014) conducted a research to achieve a better understanding of the social aspects of green purchase behavior. They examined the effects of environmental concerns of others on purchasing behavior. The results showed that environmental concerns of others reduce the likelihood of the selection of products with low environmental impact (more destructive). In this research, perceived social risk and incompatibility associated with the products against environment were considered as a mediating variable. Albayrak et al. (2013) conducted a research to investigate the impact of environmental concerns and doubts on the green purchasing behavior of customer. Their research results indicated that customers who had higher levels of concern about environment and less doubts had more positive attitudes, and showed behavioral control, and thus, had more motivation to have a stronger intention for green purchasing.

Singh and Bansal (2012) examined environmental concerns based on age and gender as demographic variables to determine consumers' attitudes towards green marketing. Then, they examined the relationship between environmental concerns and the attitudes of consumers towards green marketing. The results of their research showed that there is no difference between men and women in terms of attitude to green marketing, environmental awareness, and care for green products at the time of making purchase decisions. In addition, age, as well as concern for environmental issues, had no effect on individual attitudes towards care for green products and green marketing. The results of their research showed that there is no relationship between consumers' environmental awareness and their attitudes toward green marketing. In the meantime, they showed that there is a significant relationship between environmental concerns and attitudes towards green marketing. Hartmann and Apaolaza (2012) investigated the role of psychological interests and environmental concerns on consumers' attitudes and intention to purchase green brands. The results indicated a positive impact of attitude to green on purchasing intention. In addition, utilitarian interests, natural experiences, and environmental concerns had their impact on attitude toward the brand. Besides, increased temperature has direct impact on purchase intention, but it does not affect the attitude to brand purchasing.

Juwaheer et al. (2012) analyzed the impact of green marketing strategies on consumers purchasing pattern. Research findings indicated that in this regard environmental concerns of consumers are high. The results also showed that most consumers are interested in preserving the environment, and that there is a positive relationship between green marketing strategies and purchasing pattern of customers. Therefore, there are numerous opportunities for companies to promote green branding. Haghighi and Khalil (2012) conducted a research among students to find the sensitivity of consumers to environmental issues, their participation in social programs related to green marketing and compliance environmental issues in their consumptions. The results indicated that consumers are concerned about the environment and issues related to it, and are aware of social programs related to 
green marketing attention. Although they participate in these programs, they do not consider environmental issues in their purchasing behavior.

Khorshidi et al. (2010) investigated paying attention to environmental and personal outcomes of a particular product to assess the value variables on tendency to purchase environment-friendly products. Results of their research showed a positive correlation between paying attention to the environmental outcomes of a particular product and desire and willingness to purchase environment-friendly products. However, there was a negative correlation between the individual outcomes of a particular product and the desire to purchase environment-friendly products. Paço and Raposo (2009) in a research meant to identify the green consumer, divided consumers into uncommitted (36\%), green activists (35\%), and undecided groups (29\%) using demographic variables and environmental variables (anxiety, influence, knowledge, pro-environmental behavior, search for information, activities, green product purchasing behavior, price sensitivity, recycling, perceived efficacy and cynicism). They stated that consumers are always concerned about their environment, even if their concern is attributed to environment-friendly behaviors.

\section{Hypotheses and conceptual model}

By looking into the scientific literature and taking into account the results of studies conducted by Kumar and Ghodeswar (2015), Biswas and Mousumi (2015), Newton et al. (2015), Bertrandias and Gambier (2014), Albayrak et al. (2013), Lu et al. (2013), Juwaheer et al. (2012), Hartmann and Apaolaza (2012), Singh and Bansal (2012), and Paço and Raposo (2009), the following hypotheses were formulated:

$\mathrm{H}_{1}$ : The environmental attitude of consumers has a significant positive impact on their care for green products.

$\mathrm{H}_{2:}$ The environmental attitude of consumers has a significant positive impact on their environmental concerns.

$\boldsymbol{H}_{3}:$ Care for green products has a significant positive impact on customers' decision to purchase a green product.

$\boldsymbol{H}_{4}$ : Environmental concerns of consumers have a significant positive impact on their decision to purchase a green product.

$\boldsymbol{H}_{5}$ : Environmental concerns of consumers have a significant positive impact on their care for green products.

$\boldsymbol{H}_{6}$ : The environmental attitude of consumers has a significant positive impact on their decision to purchase a green product.

Revealing the fundamental variables of the research and creating relationships between them through the lens of the theoretical and experimental literature, the conceptual model of the research was developed as shown in Figure 1: 


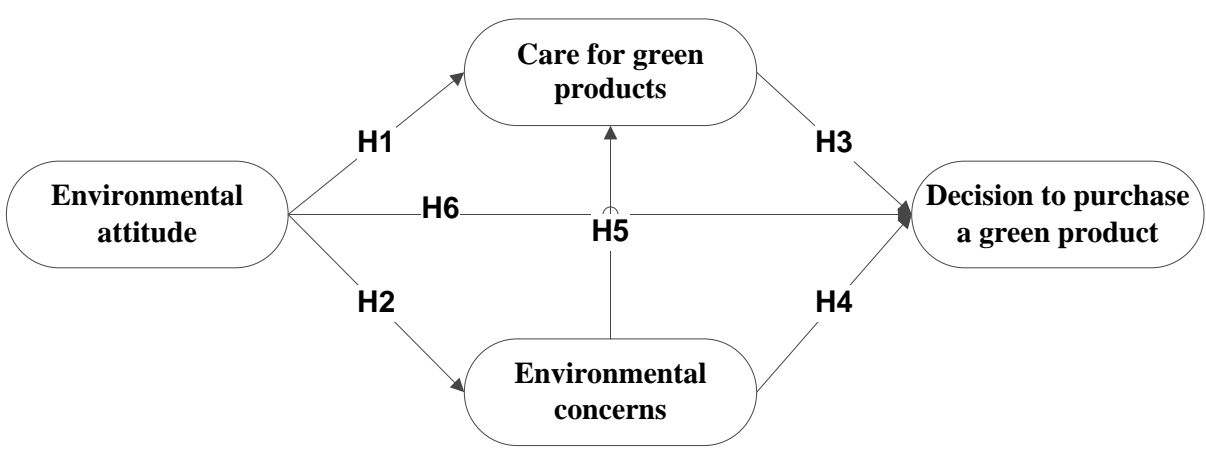

Figure 1. The conceptual model of the research

Source: Authors' own processing.

\section{Research methodology}

This research is an applied research in terms of objectives, and correlational type of survey-descriptive research in terms of collecting data. Considering the period of research, this research can be considered cross-sectional, because the data required for analysis were collected in the summer of 2016. The research population consisted of all consumers of products in the city of Bushehr (Iran). Since there was no complete information about the exact number of consumers, the research population was considered unlimited. The sample size for the research was determined to be 384 people based on Cochran sampling formula of unlimited population and $95 \%$ confidence level, a sampling error of $5 \%$, and agreement ratio of 50\%. Due to the large population and lack of development of population framework, the non-random sampling method and the available sampling method were used. In this research, 390 questionnaires were distributed among consumers in Bushehr city (Iran) in person. Eventually, 315 full questionnaires were returned.

With regard to the theoretical and experimental literature, library (printed and online books and articles) method was used, and through questionnaire the data were collected since questionnaires are considered as one of the most common methods for data collection in descriptive-survey studies. In this research the questionnaire is composed of three parts, namely introduction, demographic data, and assessing main variables of research. In the introduction, explanations are provided on objectives and the title of the research, as well as the guidelines of the questionnaire. In the demographic part of the questionnaire, questions about gender, age, marital status, education, and occupation of the subjects of research were asked. In the part on assessing the main variables of the research, 27 questions were developed through integration of the items from previous researches. In this questionnaire, the five-point Likert scale (from strongly agree to strongly disagree) was used.

The questionnaire was developed according to other researchers' questionnaire whose validity has been already been assessed. Therefore, it can be said that this questionnaire has the required validity. However, to determine validity of the questionnaire, face validity method was used. For this purpose, the developed questionnaire was provided for a number of university professors in the field of management, marketing, and consumers of Bushehr city, and they were 
asked to express their views on questionnaire validity. After collecting their views, the final questionnaire was developed. To assess the reliability of the research questionnaire, the most common method of assessment which is Cronbach's alpha coefficient was used. Cronbach's alpha coefficient for the entire questionnaire was $88.9 \%$ and for all variables was higher than 0.7 , which is a good coefficient, and suggests that the reliability of the questionnaire is at a good level. Table 1 shows information regarding the development of questions of the questionnaire and the results of the questionnaire reliability and validity indicators.

Table 1. Cronbach's alpha calculated for research variables

\begin{tabular}{|c|c|c|c|}
\hline Research Variables & $\begin{array}{c}\text { Number of } \\
\text { Questions }\end{array}$ & $\begin{array}{c}\text { Extraction source of research } \\
\text { variable items }\end{array}$ & $\begin{array}{c}\text { Cronbach's } \\
\text { alpha }\end{array}$ \\
\hline Environmental concerns & 8 & $\begin{array}{c}\text { Albayrak et al. (2013), Singh and } \\
\text { Bansal (2012) }\end{array}$ & 0.846 \\
\hline Environmental attitude & 6 & $\begin{array}{c}\text { Newton et al. (2015), Borin et al. } \\
\text { (2011) }\end{array}$ & 0.885 \\
\hline Care for green products & 8 & $\begin{array}{c}\text { Newton et al. (2015), Wang } \\
\text { (2014), Albayrak et al. (2013), }\end{array}$ & 0.930 \\
\hline $\begin{array}{c}\text { Decision to purchase a } \\
\text { green product }\end{array}$ & 5 & $\begin{array}{c}\text { Kumar and Ghodeswar (2015), } \\
\text { Haghighi \& Khalil (2012) }\end{array}$ & 0.938 \\
\hline The entire questionnaire & 27 & & 0.889 \\
\hline
\end{tabular}

Source: Authors' own processing.

In order to perform the descriptive examination of the data, SPSS software was used, and the conceptual model and research hypothesis were tested by structural equation modeling using AMOS software.

\section{Data analysis and results}

In this section, the descriptive analysis of demographic variables and variables of the research are examined. In addition, this section examines the normal distribution of data, and it analyzes the conceptual model variables of the research.

\section{Descriptive results}

For the analysis of data, descriptive statistics was used to analyze demographic variables and variables of the research. Table 2 shows the demographic variables of the research which were analyzed through collecting 315 questionnaires.

Table 2. Demographic characteristics of respondents

\begin{tabular}{|c|c|c|c|}
\hline $\begin{array}{c}\text { Demographic } \\
\text { variable }\end{array}$ & Levels & Frequency & $\begin{array}{c}\text { Percentage of } \\
\text { frequency }\end{array}$ \\
\hline Gender & Male & 134 & 42.5 \\
& Female & 181 & 57.5 \\
\hline \multirow{2}{*}{ Marital status } & Married & 203 & 64.4 \\
& Single & 112 & 35.6 \\
\hline \multirow{2}{*}{ Age } & 18 to 25 years & 42 & 13.3 \\
& 26 to 35 years & 74 & 23.5 \\
& 36 to 45 years & 82 & 26 \\
& 46 to 55 years & 63 & 20 \\
\hline
\end{tabular}




\begin{tabular}{|c|c|c|c|}
\hline & Over 55 years & 54 & 17.2 \\
\hline \multirow{3}{*}{ Education } & Diploma and lower & 84 & 26.7 \\
& Associate Degree & 27 & 8.6 \\
& Undergraduate & 146 & 46.3 \\
& Graduate and higher & 58 & 18.4 \\
\hline \multirow{5}{*}{ Type of job } & University student & 38 & 12 \\
& Worker & 93 & 29.5 \\
& Employee & 61 & 19.4 \\
& Self-employed, & 92 & 29.3 \\
& housewives and & & 9.8 \\
\hline
\end{tabular}

Source: Authors' own processing.

As Table 2 shows, the largest number of respondents were females (57.5 percent) and married people (64.4 percent). In addition, most of them (31.6\%) were self-employed, housewives, or unemployed. Most participants (26\%) belonged to the middle-aged population and most of them (46.3\%) had bachelor level of education.

Before carrying out causal analysis on data and testing hypotheses, we needed to be sure on the descriptive status of research variables. For this purpose, the present research investigated the mean value and dispersion indices. The results are shown in Table 3.

Table 3. Descriptive information of research variables

\begin{tabular}{|c|c|c|}
\hline Variable & Mean & $\begin{array}{c}\text { Standard } \\
\text { deviation }\end{array}$ \\
\hline Environmental concerns & 3.95 & 1.04 \\
\hline Environmental attitude & 3.62 & 1.18 \\
\hline Care for green products & 4.33 & 0.54 \\
\hline Decision to purchase a green product & 4.07 & 0.54 \\
\hline
\end{tabular}

Source: Authors' own processing.

As shown in Table 3, the mean of all variables is above the moderate level (3). This indicates that consumers of Bushehr city have relatively higher awareness about environmental issues and green marketing. The highest mean (4.33 out of 5) and the lowest standard deviation (0.54) are related to variable of care for green products and the lowest mean (3.62 out of 5) and the highest standard deviation (1.18) are related to variable of environmental attitudes.

\section{Testing the conceptual model}

The conceptual model and the research hypotheses were tested by using structural equation modeling and AMOS software. Implementation of structural equation modelling helps researcher to examine the theoretical pattern which consists of different elements both generally and partially. The purpose of the test is to investigate the match between the theoretical model and the experimental data collected. The elements of structural equation modelling test show that there is a significant positive relationship between the elements of different layers of research conceptual model. Figure 2 shows the results of the structural equation modeling 
test along with standardized coefficients (path coefficients) and significance of coefficients (t-value).

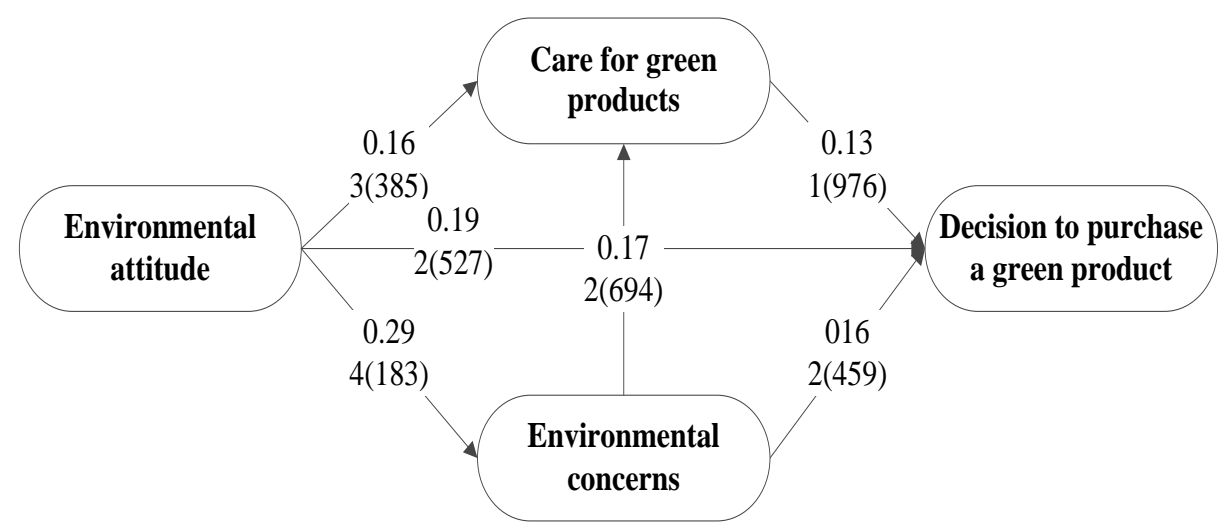

Figure 2. Implementation of structural equation model, along with standardized coefficients (path coefficients) and significance of coefficients ( $t$-value) Source: Authors' own processing.

Model fit indices are one of the important stages in the analysis of the structural equation modelling. These indices aim to answer the question whether the model represented by the data confirms the conceptual model or not. By conducting structural equation modelling test in AMOS software, it gives the fit indices which show the claimed conceptual model fit with the experimental data. Unlike conventional statistical tests confirmed or rejected by one statistic, in the structural equation modelling, to evaluate the fit of the model, a set of indices is used. However, the use of four or five indices is enough. The results of the evaluation of quality indices (suitability) are shown Table 4.

Table 4. Indicators of conceptual model fit in the implementation of structural equation modeling

\begin{tabular}{|c|c|c|c|c|c|c|c|}
\hline $\begin{array}{c}\text { Index model } \\
\text { fitting }\end{array}$ & $\mathbf{X}^{2} / \mathbf{D F}$ & $\mathbf{P}$ & CFI & NFI & RMSEA & IFI & GFI \\
\hline Acceptable fit & $\leq 1 \leq 3$ & $\geq 0.05$ & $\geq 0.9$ & $\geq 0.9$ & $\leq 0.09$ & $\geq 0.9$ & $\geq 0.9$ \\
\hline Obtained Value & 1.482 & 0.000 & 0.969 & 0.911 & 0.034 & 0.969 & 0.920 \\
\hline
\end{tabular}

The data in Table 4 indicate that the mentioned indices of the model have good status, which indicates that the data are appropriate. Therefore, based on the results of the data resulting from the implementation of a structural equations model, the conceptual model structure of research is confirmed. The overall confirmation of the conceptual model does not mean that all relationships in the model have also been confirmed.

After the overall fit of the model, all model relationships should be also tested to find out if defined relationships in the model are confirmed or not. After the extraction of structural equations model data, we can test the research hypotheses. The results of main research hypothesis testing are shown in Table 5. 
Table 5. The results of testing the main hypotheses of research

\begin{tabular}{|l|c|c|c|l|}
\hline \multicolumn{1}{|c|}{ Hypotheses } & $\begin{array}{c}\text { Standardized } \\
\text { path } \\
\text { coefficient }\end{array}$ & $\begin{array}{c}\text { Calculated } \\
\text { t-value }\end{array}$ & $\begin{array}{c}\text { P- } \\
\text { value }\end{array}$ & Result \\
\hline $\begin{array}{l}\text { Hypothesis 1: The environmental attitude of } \\
\text { consumers has a significant positive impact on } \\
\text { their care for green products. }\end{array}$ & 0.16 & 3.385 & 0.017 & Accepted \\
\hline $\begin{array}{l}\text { Hypothesis 2: The environmental attitude of } \\
\text { consumers has a significant positive impact on } \\
\text { their environmental concerns. }\end{array}$ & 0.29 & 4.183 & 0.000 & Accepted \\
\hline $\begin{array}{l}\text { Hypothesis 3: Care for green products has a } \\
\text { significant positive impact on customers' } \\
\text { decision to purchase a green product. }\end{array}$ & 0.13 & 1.976 & 0.048 & Accepted \\
\hline $\begin{array}{l}\text { Hypothesis 4: Environmental concerns of } \\
\text { consumers have a significant positive impact on } \\
\text { their decision to purchase a green product. }\end{array}$ & 0.16 & 2.459 & 0.014 & Accepted \\
\hline $\begin{array}{l}\text { Hypothesis 5: Environmental concerns of } \\
\text { consumers have a significant positive impact on } \\
\text { their care for green products. }\end{array}$ & 0.17 & 2.694 & 0.007 & Accepted \\
\hline $\begin{array}{l}\text { Hypothesis 6: The environmental attitude of } \\
\text { consumers has a significant positive impact on } \\
\text { their decision to purchase a green product }\end{array}$ & 0.19 & 2.527 & 0.012 & Accepted \\
\hline
\end{tabular}

Source: Authors' own processing.

The implementation of structural equation modelling test shows that there is a significant positive relationship between different elements of the conceptual model. According to the results obtained from the path coefficients (Figure 2) and according to what is given in Table 5 , it can be said that all hypotheses were confirmed at $95 \%$ confidence level.

\section{Conclusion and recommendations}

The aim of this research was to investigate the relationship between environmental attitudes and concern, and care for green products, in order to find the relationship between these three variables and customers' decision to purchase a green product. After theoretical and experimental review of literature, several research hypotheses and a conceptual model were developed. To collect data in this research, a 27-item questionnaire was used. In this research, 315 questionnaires were collected. Then, the conceptual model and hypotheses were tested using the collected data and structural equation modeling by AMOS software. Results revealed that the conceptual model of the research is confirmed according to model fit indices.

According to Table 5, the findings of the research showed that the environmental attitudes of consumers have positive and significant impact on care for green products. In addition, their relationship with each other was positive and they changed in the same direction. This means that as the attitude of consumers towards environmental products increases, their care for green products will also rise. The result of this hypothesis testing is in line with the findings of Lu et al. (2013), Singh and Bansal (2012). Therefore, marketers should pay more emphasis 
on the recognizable environmental benefits to enhance the customers' care for green products.

According to Table 5, it can be said that the environmental attitude of the consumer has a significant positive impact on their environmental concerns. In fact, we conclude that as the attitude towards the environment increases, environmental concerns also increase. Investigating the results of Albayrak et al. (2013), Singh and Bansal (2012) indicated that the customers who had higher levels of environmental concern and less doubts, reflected positive attitude and displayed more behavioral control and, therefore, had more motivation to purchase green products. According to the results of this research, it is recommended for marketers to focus on products that are compatible with the environment in their advertisement, because consumers welcome purchasing such products.

According to table 5, it can be said that care for green products by the consumer has a significant positive impact on his decision to purchase green products. In addition, the relationship between these two was positive and changed in the same direction. In fact, this hypothesis implies that as more care is given for green products, the consumers' decision purchase them increases. The findings of this research are in line with the research results of Kumar and Ghodeswar (2015), Singh and Bansal (2012), and Khorshidi et al. (2010). The results of their research suggest that support of the environment preservation, driving with environmental responsibility, experience of the green product, the friendship of companies with environment and social accountability are considered as the most important factors influencing the decision to purchase green products. Given that purchasers who care more for green products collect much relevant information, it is recommended for marketers to avoid providing incomplete information on production, packaging, and pricing for their products, and try to give complete information to purchasers.

According to Table 5, it can be said that the consumers' environmental concern has significant and positive impact on their decision to purchase green products. This means that as the environmental concerns of the consumer increase, green purchasing decision will also increase. Biswas and Mousumi (2015), Bertrandias and Gambier (2014), Albayrak et al. (2013) were among the researchers who found similar results. They believed that the environmental concerns affect purchasing intention directly. Environmental concerns of consumers also reduce the possibility of choosing the products with low environmental impact (more destructive products). According to the result of this research, it is recommended for marketers to pay more attention to green products benefits in their advertisements and to draw the attention of the purchasers to such products by providing comparative advertisements, and to express the value of these products for purchasers to increase the green purchasing decision of the customers.

According to Table 5, it can be said that the environmental concerns of the consumer have a significant and positive impact on their care for green products. This means that as their environmental concerns rises, their care for green products will also increase. Newton et al. (2015) were also among the researchers whose research results were in line with these findings. With regard to this conclusion, we recommend to marketers to encourage the purchasers and customers who pay 
attention to green products to consider social and environmental criteria in use, disposal time of waste and their purchase.

According to Table 5, it can be said that the environmental attitude of the consumer has a significant positive impact on his decision to purchase green products. Lu et al. (2013), Singh and Bansal (2012), Abedi and Hasani (2015), and Ranaee and Yari (2013) are among the researchers who found similar results. The results of their research suggest that attitude about the product has a positive and significant impact on one's intention to purchase environment-friendly products. In this regard, given that environmental ads facilitate the perceptions and awareness to the specifications and characteristics of green products, it is recommended to them to guide customers to purchase environment-friendly products.

\section{Applied recommendations}

The results of this research can be used by all companies involved in green marketing. According to the findings of the research, the following applied recommendations are provided for companies:

1. As the environmental attitude of the consumer is positively and significantly correlated with their care for green products, it is recommended that marketers use advertising slogans and strategies based on the correct information to strengthen the attitude created in customers in a positive direction in order to increase the care that customers give for green products.

2. As care for green products is directly and positively correlated with their purchasing decision, it is recommended that marketers emphasize on the importance and benefits of using and consumption of green products. In addition, it is recommended that they encourage the customers toward purchasing green products, emphasizing on responsibility and complying with social responsibility.

3. According to the findings of the research on the relationship between environmental concerns of the consumer and decision to purchase green products, marketers could emphasize that purchasing green products is a way to help solve environmental problems because it leads to producing products which have enough durability, safety, and health.

4. According to the social pressure that leads to people's awareness on the benefits of choosing green products and an increase in purchasing them, it is recommended that those products to be provided in a way that all people have a positive view of them through showing their characteristics, prices and other features clearly and nicely.

5. It is recommended for marketers to avoid using exaggerated slogans about green products, since the expectations of purchasers would be increased and their perceptions might be destructed when their received products do not match with their expectations.

6. As those purchasers who care more for green products collect much information, it is recommend for marketers to avoid providing incomplete information about these products, on the manner of production, price and so on. They should try to provide complete information for customers.

7. Given that consumers are the ultimate users of green products, it is recommended to marketers to provide necessary information for customers 
through environmental labels or advertising to help them make appropriate decisions.

8. As it is important for customers to know which products to spend their money on, it is recommended for marketers to emphasize on the benefits of green products in their advertisements. Therefore, considering the fact that as income of people increases, their purchasing problems reduce, it is recommended for marketers to emphasize on environmental aspects of these products in order to create competitive advantage for themselves, instead of focusing on price and benefits and cost-effectiveness of the products.

9. It is also recommended for marketers to emphasize on the products that have appropriate and environment-friendly packaging in their advertisements, because consumers welcome to purchase such products.

10. Marketers are recommended that in their promotion activities, they need to emphasize to customers who pay attention to green products to consider social and environmental criteria in using, time of disposal of waste and purchases.

\section{Limitations of the research and recommendation for future research}

Despite the effort for full implementation of this research and to provide a framework helping for expanding the literature, several limitations continue to remain which future studies should consider. One of the limitations of this research was access to consumers who are the real purchasers of green products. To conduct the research, we needed consumers who had at least once experienced purchasing green products and were involved in the related environmental issues. Additionally, data collection tool was a questionnaire, which as a data collection tool has some shortcomings that could affect the results of this research. Moreover, collecting data was conducted in person, and lack of expression of the reality by some consumers on their purchasing behavior could be considered another limitation of the research. In this research, the variables of the dimensions of marketing mix were not taken into account. It is recommended that future research add the dimensions of green marketing mix to the conceptual model to achieve more complete information and applied results. In addition, it is recommended that before studying customers' purchasing and consuming behavior, green products need to be provided for them.

\section{References}

Abbasi, C., Enayati, G. and Rahbari, M. (2013), "Factors influencing the green purchasing behavior of Iranian Students (Case Study: Students of Islamic Azad University of Qazvin)”, Journal of Management, Vol. 9, No. 3, pp. 36-49.

Abedi, H. and Hasani, A. (2015), "Attitudes of consumers to environment-friendly products and non-and intention to purchase them in the durable consumer goods sector (Case Study: Zanjan city)", Iranian Energy and Environment Conference, Shiraz: International Institute for Research and Education of Kharazmi.

Albayrak, T., Aksoy, S. and Caber, M. (2013), "The effect of environmental concern and scepticism on green purchase behaviour", Marketing Intelligence \& Planning, Vol. 31, No. 1, pp. 27-39. 
Belz, F. and Peattie, K. (2009), Sustainability marketing: A global perspective, Wiley: Chichester.

Bertrandias, L. and Gambier, L. (2014), “Others' environmental concern as a social determinant of green buying", Journal of Consumer Marketing, Vol. 31, No. 6, pp. 417-429.

Biswas, A. and Mousumi, R. (2015), "Green products: an exploratory study on the consumer behaviour in emerging economies of the East", Journal of Cleaner Production, Vol. 87, No. 1, pp. 463-468.

Bonini, S. and Oppenheim, J. (2008), "Cultivating the green consumer", Stanford Social Innovation Review, Vol. 47, No. 3, pp. 56-61.

Borin, N., Cerf, D. and Krishnan, R. (2011), "Consumer effects of environmental impact in product labeling", Journal of Consumer Marketing, Vol. 28, No. 1, pp. 76-86.

Brécard, D., Hlaimi, B., Lucas, S., Perraudeau, Y. and Salladarré, F. (2009), "Determinants of demand for green products: An application to eco-label demand for fish in Europe", Ecological Economics, Vol. 69, No. 1, pp. 115-125.

Chahal, H., Dangwal, R. and Raina, S. (2014), "Conceptualisation, development and validation of green marketing orientation (GMO) of SMEs in India", Journal of Global Responsibility, Vol. 5, No. 2, pp. 312-337.

Chamorro, A. and Banegil, T. (2006), "Green marketing philosophy: a study of Spanish firms with ecolables", Corporate Social Responsibility and Environmental Management, Vol. 31, No. 1, pp. 11-24.

Chan, E. (2013), "Managing green marketing: Hong Kong hotel managers' perspective", International Journal of Hospitality Management, Vol. 34, No. 4, pp. 442-461.

Chen, Y. and Chang, C. (2013), "Greenwash and green trust: the mediation effects of green consumer confusion and green perceived risk", Journal of Business Ethics, Vol. 114, No. 3, pp. 489-500.

Chiou, T., Chan, H., Lettice, F. and Chung, S. (2011), "The influence of greening the suppliers and green innovation on environmental performance and competitive advantage in Taiwan", Transportation Research Part E, Vol. 47, No. 6, pp. 822-836.

Cleveland, M., Kalamas, M. and Laroche, M. (2005), "Shades of green: linking environmental locus of control and pro-environmental behaviors", Journal of Consumer Marketing, Vol. 22, No. 4, pp. 198-212.

Czap, N.A. (2010), "An experimental investigation of revealed environmental concern", Ecological Economics, Vol. 69, No. 10, pp. 2033-2041.

Dangelico, R. and Pontrandolfo, P. (2009), "From green product definitions and classifications to the Green Option Matrix", Journal of Cleaner Production, Vol. 18, No. 16, pp. 1608-1628.

Elahi, S. and Yaghubi, R. (2012), "The introduction of green marketing tools and their impact on consumer purchasing behavior", Improvement and transformation management studies, Vol. 21, No. 5, pp. 167-168.

Finisterra do Paco, A., Barata Raposo, M. and Filho, W. (2009), "Identifying the green consumer: a segmentation study", Journal of Targeting, Measurement \& Analysis For Marketing, Vol. 17, No. 1, pp. 17-25. 
Gadenne, D., Sharma, B., Kerr, D. and Smith, T. (2011), “The influence of consumers' environmental beliefs and attitudes on energy saving behaviour", Energy Policy, Vol. 39, No. 12, pp. 7684-7694.

Haghighi, M. and Khalil, M. (2012), "Investigating the place of green marketing in consumer purchasing behavior", Organizational Culture Management, Vol. 9, No. 1, pp. 83-102.

Hartmann, P. and Apaolaza-Ibáñez, V. (2012), "Consumer attitude and purchase intention toward green energy brands: The roles of psychological benefits and environmental concern", Journal of Business Research, Vol. 65, No. 9, pp. 12541263.

Hosseini, M. and Ziaee Bideh, A. (2014), "Classification and determining the profiles of green users using self-organizing maps", Management Studies in Iran, Vol. 17, No. 2, pp. 44-67.

Juwaheer, T., Pudaruth, S. and Noyaux, M. (2012), "Analysing the impact of green marketing trategies on consumer purchasing patterns in Mauritius", World Journal of Entrepreneurship, Management and Sustainable Development, Vol. 8, No. 1, pp. 36-59.

Kamble, V. (2007), "Incandescent bulbs; A burnt out case?", Dream, Vol. 9, No. 9, pp. 2047-2061.

Khorshidi, G., Banoei, A. and Sarvi, H. (2010), "Investigating the effect of value variables on tend to purchase environment-friendly products", Management Perspective, Vol. 9, No. 3, pp. 81-98.

Kumar, P. (2014), "Greening retail: an Indian experience", International Journal of Retail \& Distribution Management, Vol. 42, No. 4, pp. 613-625.

Kumar, P. and Ghodeswar, B. (2015), “Factors affecting consumers' green product purchase decisions", Marketing Intelligence \& Planning, Vol. 33, No. 3, pp. 330347.

Lassner, E. and Schubert, W.-D. (2007), "Tungsten is still very much an element of lighting", 20th Annual General Meeting of Inernational Tungsten Industry Association.

Lee, K. (2008), "Opportunities for green marketing: young consumers", Marketing Intelligence \& Planning, Vol. 26, No. 6, pp. 573-586.

Lu, L., Bock, D. and Joseph, M. (2013), "Green marketing: what the Millennials buy", Journal of Business Strategy, Vol. 34, No. 6, pp. 3-10.

Magnier, L. and Crié, D. (2015), "Communicating packaging eco-friendliness: An exploration of consumers' perceptions of eco-designed packaging", International Journal of Retail \& Distribution Management, Vol. 43, No. 4, pp. 350-366.

Matthes, J., Wonneberger, A. and Schmuck, D. (2014), "Consumers' green involvement and the persuasive effects of emotional versus functional ads", Journal of Business Research, Vol. 67, No. 9, pp. 1885-1893.

Montague, J. and Mukherjee, A. (2010), "Marketing green products: what really matters?", Proceedings of the Northeast Business and Economics Association, pp. 433-441. 
Nakhee, A. and Kheiri, B. (2013), "Investigating the effects of selected factors on intention to purchase green products", Journal of Marketing Management, Vol. 7, No. 1, pp. 107-130.

Newton, J., Tsarenko, Y., Ferraro, C. and Sands, S. (2015), "Environmental concern and environmental purchase intentions: The mediating role of learning strategy", Journal of Business Research, Vol. 68, No. 9, pp. 1974-1981.

Oliver, J. and Lee, S. (2010), "Hybrid car purchase intentions: a cross-cultural analysis", Journal of Consumer Marketing, Vol. 27, No. 2, pp. 96-103.

Paço, A. and Raposo, M. (2009), "Green segmentation: An application to the Portuguese consumer market", Marketing Intelligence and Planning, Vol. 27, No. 3, pp. 364-379.

Papadopoulos, I., Karagouni, G., Trigkas, M. and Evanthia Platogianni. (2010), “Green marketing: The case of Greece in certified and sustainably managed timber products", EuroMed Journal of Business, Vol. 5, No. 2, pp. 166-190.

Peattie, K. and Crane, A. (2005), "Green marketing: legend, myth, farce or prophesy?", Qualitative Market Research: An International Journal, Vol. 8, No. 4, pp. 357-370.

Polonsky, M. (1995), "Stakeholder theory approach to designing environmental marketing strategy", Journal of Business \& Industrial Marketing, Vol. 10, No. 3, pp. 29-46.

Ramayah, T., Chow Lee, J. and Mohamad, 0. (2010), "Green product purchase intention: Some insights from a developing country", Resources, Conservation and Recycling, Vol. 54, No. 12, pp. 1419-1427.

Ranaee, H. and Yari, B. (2013), "Investigating the effect of the marketing mix of green marketing on green purchasing decision of consumers (Case Study: Consumers of Pegah dairy products company in the city of Shiraz)", Journal of New Marketing Research, Vol. 2, No. 2, pp. 92-65.

Rusta, A., Venus, D. and Abrahami, A. (2008), Marketing management, Tehran: Organization of Study and Compilation of Humanities Books.

Salarzehi, H. and Jahromy, A. (2015), New approaches to marketing, Tehran: Mehrban Book.

Singh, A. and Bansal, M. (2012), "Green marketing: A study of consumer attitude and environment concern", The Indian Journal of Commerce, Vol. 65, No. 2, pp. 273283.

Stern, P. (2000), "Toward a coherent theory of environmentally significant behaviour", Journal of Social Issues, Vol. 56, No. 3, pp. 407-424.

Wang, S. (2014), "Consumer characteristics and social influence factors on green purchasing intentions", Marketing Intelligence \& Planning, Vol. 32, No. 7, pp. 738-753. 